\title{
Principles of Antibiotic Therapy in Orthopedic Surgery
}

\author{
S Venkatesh Babu
}

\author{
Abstract \\ This article displays the current ideology in the therapy of antibiotics. It also explains the various guidelines for safe usage with a precise choice \\ of antibiotics in orthopedic and trauma surgery including prophylaxis in the prevention of surgical site infection. \\ Keywords: Antibiotics, Infection, Injury, Orthopedics, Principles, Surgery. \\ Journal of Orthopedics and Joint Surgery (2021): 10.5005/jp-journals-10079-1029
}

\section{INTRODUCTION}

The World Health Organization (WHO) estimates $>50 \%$ of antibiotics in many countries are used inappropriately. Hence, in its latest advisory, WHO suggested the adoption of "Access, Watch and Reserve"; an approach that specifies which antibiotics to use for the most common and serious infections, which ones ought to be available at all times in the healthcare system, and those to be used sparingly or reserved or used as last resort. World Health Organization has also urged all countries to adopt these guidelines to reduce the antimicrobial resistance, adverse events, and costs of the treatment. ${ }^{1}$

The efficacy of prophylactic antibiotics has been well established in orthopedic surgery. ${ }^{2}$ The antibiotic administration is effective at reducing infection when administrated just before the surgical incision is made. Multiple studies had confirmed this fact in joint arthroplasty, fracture surgery, and spine surgery. ${ }^{3}$ Despite that, surgical site infections (SSIs) continue to be a major source of morbidity, mortality, and hospital cost. ${ }^{4,5}$

The incorrect use of antibiotics and easy access fuel antibiotic resistance which is a growing concern worldwide and in India. The recent Indian study confirmed the overuse of antibiotics in our country with antibiotic prescription rate is high in the private sector and advocated antibiotic stewardship programs (ASP) in the healthcare institutions. This study also highlighted that primary care physicians in the private sector of our country can play a key role in reducing antibiotic misuse and overuse. ${ }^{4,6-8}$

The Health Department of Government of India through its Indian Council of Medical Research and National Centre of Disease Control had laid down guidelines in antimicrobial usage in our country focusing the effectiveness and cost reduction. These guidelines are advocating the precise choice of antibiotics and duration to be used in all specialties including orthopedic and fracture surgery..$^{9,10}$

Surgical site infection in orthopedic implant surgery is a serious complication ranges from 2 to $22 \%$. It leads to increase morbidity and cost of treatment. ${ }^{11}$ Today, the medical planet is advising ASPs in all the clinical establishments. The goals of these programs are to decrease hospital-acquired infections, control costs, and prevent complications associated with antibiotic usage (e.g., renal damage, Clostridium difficile infections). The stewardship team consists of surgeons, infectious disease specialists, clinical pharmacists, infection control, and prevention practitioners., ${ }^{42}$
Department of Orthopaedics and Trauma Surgery, Sri Sakthi Hospital, Tirunelveli, Tamil Nadu, India

Corresponding Author: S Venkatesh Babu, Department of Orthopaedics and Trauma Surgery, Sri Sakthi Hospital, Tirunelveli, Tamil Nadu, India, Phone: +91 9843057118, e-mail: drsvbabu@hotmail.com How to cite this article: Venkatesh Babu S. Principles of Antibiotic Therapy in Orthopedic Surgery. J Orth Joint Surg 2021;3(1):51-53.

Source of support: Nil

Conflict of interest: None

\section{Microorganisms Prevalence and Antibiotic Therapy in Orthopedic Surgery ${ }^{9-17}$}

As per the 2017 Guidelines from Indian Medical Council Research, Staphylococcus aureus and coagulase-negative Staphylococci and gram-negative bacilli dominate acute osteomyelitis, septic arthritis, SSIs of spine surgery, arthroplasties, fracture surgery with internal fixation devices, functional tissue repair, and trauma. In external fixation, the commonest organism causing an infection are Staphylococcus aureus, Staphylococcus epidermidis, and Escherichia coli, especially in children. In chronic osteomyelitis or synovitis, there is no empiric therapy and the definitive treatment has to be directed by bone/synovial biopsy culture and will be for a minimum of 6 weeks.

Orthopedic surgery is a unique specialty where the utmost care in the prevention of Infection is warranted. There are more bone and joint surgeries performed today than in yesteryears. They are indeed justified well considering the early mobility and improving the quality of life. The overall incidence of orthopedic SSI ranges from 0.8 to $71 \%$. Also, the increasing incidence of road traffic accidents and traumatic injuries in India contributes more to open fractures demanding antibiotics. The following tabloid exhibits the specific organisms and their choice of antibiotics in orthopedic and trauma surgery (Table 1).

\section{Antibiotic Prophylaxis in Orthopedic and Trauma Surgery $2,3,7,9,18,19$}

The value of prophylactic antibiotics in orthopedic surgery has been well recognized today. It had been proved that antibiotic administration is valuable at reducing infection and sepsis after orthopedic surgery. It is advised to give antibiotic infusion 15-30

\footnotetext{
(c) The Author(s). 2021 Open Access This article is distributed under the terms of the Creative Commons Attribution 4.0 International License (https:// creativecommons.org/licenses/by-nc/4.0/), which permits unrestricted use, distribution, and non-commercial reproduction in any medium, provided you give appropriate credit to the original author(s) and the source, provide a link to the Creative Commons license, and indicate if changes were made. The Creative Commons Public Domain Dedication waiver (http://creativecommons.org/publicdomain/zero/1.0/) applies to the data made available in this article, unless otherwise stated.
} 
Table 1: The display of organisms and choice of antibiotics in orthopedic surgery

\begin{tabular}{|c|c|c|c|c|}
\hline Disease/challenge & Microorganisms & First choice & Second choice & Route/duration \\
\hline $\begin{array}{l}\text { Cellulitis/soft tissue } \\
\text { infection/lymphangitis }\end{array}$ & $\begin{array}{l}\text { Group I Streptococcus } \\
\text { pyogenes, Staphylococcus } \\
\text { aureus }\end{array}$ & $\begin{array}{l}\text { Cloxacillin (50-100 mg/kg/ } \\
\text { day) in 3-4 divided doses or } \\
\text { Co-amoxiclav }(1.2 \mathrm{~g}) \mathrm{BD} \text { or } \\
\text { Inj. Cefazolin }(50 \mathrm{mg} / \mathrm{kg} / \mathrm{day} \\
\text { in BD) }\end{array}$ & $\begin{array}{l}\text { Clindamycin } 600 \mathrm{mg} \text { 8th } \\
\text { hourly in penicillin-allergic } \\
\text { patients }\end{array}$ & IV/5-7 days \\
\hline $\begin{array}{l}\text { Acute osteomyelitis/ } \\
\text { septic arthritis }\end{array}$ & $\begin{array}{l}\text { Staphylococcus aureus/ } \\
\text { group I Streptococcus } \\
\text { pyogenes }\end{array}$ & $\begin{array}{l}\text { Co-amoxiclav }(1.2 \mathrm{~g}) \mathrm{BD} \text { and } \\
\text { gentamycin } 80 \mathrm{mg}\end{array}$ & $\begin{array}{l}\text { Inj. ceftriaxone } 1 \mathrm{~g} / \mathrm{Inj} \text {. } \\
\text { cefotaxime } 1 \mathrm{~g} \text { with or with- } \\
\text { out Inj. vancomycin } 1 \mathrm{~g}\end{array}$ & IV/4-6 weeks \\
\hline Chronic osteomyelitis & $\begin{array}{l}\text { Multiple organisms } \\
\text { including gram-negative } \\
\text { bacilli, anaerobes }\end{array}$ & $\begin{array}{l}\text { Pathogen-specific antibiotics } \\
\text { after culture and bone biopsy }\end{array}$ & - & $\begin{array}{l}\text { Longer duration than } \\
6 \text { weeks }\end{array}$ \\
\hline $\begin{array}{l}\text { Surgical site infection/ } \\
\text { implant surgery } \\
\text { infection }\end{array}$ & $\begin{array}{l}\text { Staphylococcus aureus } \\
\text { and coagulase-negative } \\
\text { Staphylococci and gram- } \\
\text { negative Bacilli }\end{array}$ & $\begin{array}{l}\text { Ceftriaxone } 2 \text { g IV OD with Inj. } \\
\text { vancomycin } 1 \text { g IV BD }\end{array}$ & $\begin{array}{l}\text { Inj. teicoplanin } 800 \mathrm{mg} \text { three } \\
\text { doses/12 hours followed by } \\
400 \mathrm{mg} \text { once daily }\end{array}$ & IV/4 weeks \\
\hline Open fractures & $\begin{array}{l}\text { Staphylococcus aureus and } \\
\text { coagulase-negative Staphy- } \\
\text { lococci and gram-negative } \\
\text { Bacilli }\end{array}$ & $\begin{array}{l}\text { Co-amoxiclav }(1.2 \mathrm{~g}) \mathrm{BD} / \mathrm{ce}- \\
\text { furoxime }(1.5 \mathrm{~g}) 8 \text { th hourly }\end{array}$ & $\begin{array}{l}\text { Clindamycin } 600 \mathrm{mg} \text { 8th } \\
\text { hourly in penicillin-allergic } \\
\text { patients }\end{array}$ & $\begin{array}{l}\text { IV/continued until } \\
\text { wound debridement }\end{array}$ \\
\hline
\end{tabular}

Table 2: The display of choice of prophylactic antibiotics in orthopedic and trauma surgery

Orthopedic surgery and closed fracture surgery

Trauma surgery and open fracture surgery
Inj. cefuroxime $1.5 \mathrm{~g}$ IV Stat and BD for 24 hours (maximum) or Inj. cefazolin 2 g IV Stat and BD for 24 hours

Inj. cefuroxime $1.5 \mathrm{~g}$ IV Stat and BD for 24 hours (maximum) or Inj. cefazolin $2 \mathrm{~g}$ IV Stat and BD for 24 hours-The antibiotics are recommended and continued until wound debridement (excision)

minutes by intravenous route before starting surgery. However, there is evidence suggesting that there are no antibiotics needed for orthopedic surgery without implants and the same applies to soft tissue surgery in orthopedics. For open fractures, antibiotic prophylaxis and antitetanus measures to be provided in the emergency room itself. The antibiotics are recommended and continued until wound debridement (excision) (Table 2).

\section{Antibiotic Stewardship Program in Orthopedic Surgery $4,8,20,21$}

At present, the medical society is recommending ASPs in all the clinical establishments to manage SSIs with judicious use of antibiotics. Their efficacy had been shown with good results in challenging the microorganisms. A multidisciplinary team approach to antibiotic stewardship can lead to improved patient outcomes and cost-effective medical care. Following principles play a crucial part in the ASP in providing high-quality orthopedic surgical care:

- Determining appropriate indications of antibiotic administration.

- Choosing the correct antibiotic based on known or expected pathogens.

- Determining the correct dosage.

- Determining the appropriate duration of treatment.

These programs direct and provide expert guidance on the judicious usage of antibiotics.

\section{Discussion}

Certain factors contribute to infection in surgery. It may be a patient factor or procedural factor. The patient factors are extremes of age, immunosuppression, diabetes mellitus, anemia, smoking, prolonged hospital stay, coexisting infections at other sites, obesity, malnourishment, and carriage of resistant organisms. The procedural factors are surgical technique, longer surgical duration, inadequate hemostasis, variations of body temperature, skin antisepsis, operating theater ventilation and air changes, the presence of a foreign body, tissue trauma, and preoperative shaving of hair., ${ }^{7,11}$

Microbiological diagnosis is very important in diseases caused by a spectrum of bacterial species. Antibiotic use for nonbacterial infections leads to the risk of the development of bacterial antibiotic resistance. Correct diagnosis of specific bacterial infections is the key to limiting unnecessary prescribing. Bacterial eradication should be the primary goal of antibiotic therapy. Antibiotic choices must reflect local resistance prevalence. We have to think of pharmacokinetics and pharmacodynamics to choose the most effective agent and dosage. Consider local resistance, efficacy, and maximize cost-effectiveness while prescribing antibiotic therapy. We have to prescribe antibiotics empirically but intelligently. We have to encourage patient compliance. For patients with recurrent infections, consider taking microbiological samples and review the antimicrobial prescription when the results are available. Avoid treatment for colonization without evidence of infection unless there is a clear indication in the guidelines.

\section{Conclusion}

With regard to infection, we have to have a high index of suspicion for 3 months following orthopedic surgery. The choice of antibiotics depends on the antibiotic susceptibility of the causative organism. The most effective, least toxic, and least expensive antibiotic for the precise duration of time is needed to cure or prevent infection. The antibiotic chosen must cover the main contaminant flora present in the skin or mucosa disrupted by the incision. 
The National guidelines are to be followed for the antibiotic prescription in orthopedic and fracture surgery with the shortest effective course, most appropriate dose with the right route of administration. It is highly recommended to implement ASP in the health establishments providing orthopedic surgical care.

\section{Ethical Approval}

This article does not contain any studies with human participants or animals performed by any of the authors.

\section{References}

1. WHO Model List of Essential Medicines for 2017, Press Release of World Health Organisation, Geneva on 6 June 2017.

2. Oishi CS, Carrion WV, Hoaglund FT. Use of parenteral prophylactic antibiotics in clean orthopaedic surgery: a review of literature. Clin Orthop Relat Res 1993;296:249-255.

3. Standards for the management of open fractures of the lower limb (2009), The British Association of Plastic, Reconstructive and Aesthetic Surgeons.

4. Campbell KA, Stein S, Looze C, et al. Antibiotic stewardship in orthopaedic surgery: principles and practice. J Am Acad Orthop Surg 2014;22(12):772-781. DOI: 10.5435/JAAOS-22-12-772.

5. Rajkumari N, Gupta AK, Mathur P, et al. Outcomes of surgical site infections in orthopaedic trauma surgeries in a tertiary care centre. J Postgrad Med 2014;60(2):254-259. DOI: 10.4103/0022-3859.138731.

6. Varley AJ, Sule J, Absalom AR. Principles of antibiotic therapy, continuing education in anaesthesia. Critical Care Pain 2009;9(6):184188. DOI: $10.1093 /$ bjaceaccp/mkp035.

7. Dryden M. Surgical antibiotic prophylaxis. Surgery 2018;37(1):19-25.

8. Farooqui HH, Mehta A, Selvaraj S. Outpatient antibiotic prescription rate and pattern in the private sector in India: evidence from medical audit data. PLoS One 2019;14(11):e0224848. DOI: 10.1371/journal. pone.0224848.
9. National Treatment Guidelines for Antimicrobial Use in Infectious Diseases, National Centre for Disease Control, Directorate General of Health Services, Ministry of Health \& Family welfare, Government of India, 2016.

10. Treatment Guidelines for Antimicrobial use in common syndromes, Indian Council of Medical Research, Department of Health Research, New Delhi, India 2017.

11. Amaradeep G, Shivaprakash SS, Manjappa CN. Surgical site infections in orthopaedic implant surgery and its risk factors: a prospective study in teaching hospital. Int J Orthop Sci 2017;3(3):169-172.

12. Road Accidents Analysis in Tamil Nadu, January 2019, Home (Transport) Department, Government of Tamil Nadu.

13. Leekha S, Terrell CL, Edson RS. General principles of antibiotic therapy. Mayo Clin Proc, 2011;86(2):156-167. DOI: 10.4065/mcp.2010. 0639.

14. Salkind AR, Rao KC. Antibiotic prophylaxis to prevent surgical site infections. Am Family Physic 2011;83(5):585-590.

15. Chahoud J, Kanafani Z, Kanj SS. Surgical site infections following spine surgery: eliminationg the controversies in the diagnosis. Front Med 2014;1(7):1-9. DOI: 10.3389/fmed.2014.00007.

16. Ceroni D, Grumetz C, Desvachez O, et al. From prevention of pin-tract infection to treatment of osteomyelitis during paediatric external fixation. J Child Orthop 2016;10(6):605-612. DOI: 10.1007/s11832-0160787-8.

17. Damian Dhar A. Cellulitis - Symptoms, Causes \& Treatment, MSD Manual Consumer Version, October 2019.

18. Soriano A, Garcia-Ramiro S, Mensa J. Infection and local treatment in orthopaedic surgery. ch. 5. Springer; 2019. pp. 49-57.

19. Surgical site infections: prevention and treatment (2019), NICE Guidelines, UK.

20. Antimicrobial stewardship: systems and processes for effective antimicrobial medicine use (2015), NICE Guidelines, UK.

21. Antimicrobial stewardship programmes in health care facilities in Low and middle income countries, A World Health Organisation (WHO) Tool Kit, 2019. 